\title{
Glutamate Dehydrogenase 1 Hyperinsulinism
}

National Cancer Institute

\section{Source}

National Cancer Institute. Glutamate Dehydrogenase 1 Hyperinsulinism. NCI Thesaurus.

Code C131832.

Hyperinsulinism due to activating mutation(s) in the GLUD1 gene, encoding glutamate dehydrogenase 1 . This condition is characterized by protein induced hypoglycemia and hyperammonemia, which is presumed to be due to increased ammonia production in the kidney. 